\title{
European Union's tobacco products directive
}

\author{
Many questions remain about the influence of industry
}

\author{
Martin McKee professor of European public health
}

London School of Hygiene and Tropical Medicine, London WC1H 9SH, UK

On 8 October 2013, the European Union moved a step closer to strengthening tobacco control when members of the European Parliament (MEPs) voted for a European Commission proposal for a revised directive on tobacco products, albeit with extensive amendments. The appointed rapporteur, Linda McAvan MEP, will now seek agreement with representatives of the commission and the Council of the European Union (comprising national governments).

It is remarkable that the proposal has made it this far. The tobacco industry did everything possible to derail it, with Philip Morris spending up to $€ 1.25 \mathrm{~m}(£ 1.06 \mathrm{~m} ; \$ 1.7 \mathrm{~m})$ in 2012 in intensive lobbying, ${ }^{1}$ mostly directed at MEPs. ${ }^{2}$ However, the legislation still faces many risks. The parliament, commission, and council must agree on the text, and the council presidency will rotate from Lithuania, whose health minister is a staunch advocate of tobacco control, to Greece, where Philip Morris is investing heavily in a new distribution facility. ${ }^{3}$

So what does the legislation currently propose? It builds on the 2001 Tobacco Products Directive that increased the size of compulsory labels on cigarette packs and allowed member states to introduce graphic warnings. ${ }^{4}$ However, many of the commission's proposals have been watered down, whereas some of the most effective, such as standardised packaging and bans on point of sale displays, were removed earlier.

The proposal that pictorial warnings cover $75 \%$ of both sides of packs was reduced to $65 \%$, better than the industry's goal of $50 \%$. Moreover, the warning must be at the top of the pack and not, as industry wanted, at the bottom, where it could easily be hidden by display cases. Cigarettes will no longer be sold in packs of 10, which are more affordable for children. Provisions to increase traceability of cigarettes will be strengthened to tackle smuggling, in which the industry has been complicit. ${ }^{5}$ However, the effectiveness of these provisions is questionable-Interpol is supporting a system with known weaknesses, developed after a $\$ 15 \mathrm{~m}$ grant from Philip Morris. ${ }^{6}$ The earlier directive required additives simply to be listed. Now, those that impart a flavour will be banned, except for menthol, which will be permitted for another five years. This is a great victory for the industry, which adds menthol to about $90 \%$ of its products, even when not described. ${ }^{7}$ Menthol interacts with nicotine to increase the impact of the first inhalation and reduces the throat irritation experienced by novice smokers. ${ }^{8}$ Consequently, many products have been designed to maximise these effects. The industry also benefits from the widespread view that menthol cigarettes are healthier. ${ }^{9}$

The most contentious area is e-cigarettes. The commission proposed treating them like any other nicotine delivery device and regulating them as drugs, a view supported by many governments, including that of the United Kingdom, after careful review of the evidence. The parliament was, however, influenced by intensive lobbying against this, although the meaning of the alternative text is unclear. Now, "all nicotine containing products" will be subject to the same restrictions on cross border advertising and sponsorship as cigarettes. Although cigarette brand names will be banned, the many flavourings, such as bubble gum and cotton candy, which increase their appeal to children, will not. However, the draft text goes on to urge governments to "ensure that they can be made available as widely as tobacco products," reflecting unsubstantiated claims that they are a "game changer" for smoking cessation. ${ }^{10}$ The draft legislation fails to address the rapid growth in sales of products designed to resemble real cigarettes as closely as possible. This subterfuge is widely viewed as a way to renormalise smoking, a key goal of those seeking to recruit child smokers, and to counter some of the effects of smoking bans. ${ }^{11}$ Fortunately, nothing prevents governments from adopting more effective legislation, such as standardised packaging, but much needs to be done before a workable text is ready, and it is unfortunate that so many opportunities have been missed. However, this experience may bring other benefits. The co-chair of the parliament's public health committee has condemned most MEPs for doing "the bidding of the tobacco industry," "1 focusing much needed attention on the role of industry lobbyists in Brussels.

Competing interests: I have read and understood the BMJ Group policy on declaration of interests and declare the following interests: None.

Provenance and peer review: Commissioned; not externally peer reviewed.

\footnotetext{
Nielsen N. Tobacco giant spent up to $€ 1.25 \mathrm{mn}$ on EU lobbying in 2012. Euobserva 2013.
} http://euobserver.com/institutional/121657. 
2 Corporate Europe Observatory. Tobacco lobbyists all fired up ahead of key vote. 2013. http://corporateeurope.org/lobbycracy/2013/07/tobacco-lobbyists-all-fired-ahead-key-vote. Philip Morris to set up logistics hub in western Greece. Ekathimerini 2013. www. ekathimerini.com/4dcgi/_w_articles_wsite2_1_29/08/2013_516174.

4 Directive 2001/37/Ec of the European Parliament and of the council of 5 June 2001 on the approximation of the laws, regulations and administrative provisions of the member states concerning the manufacture, presentation and sale of tobacco products. Official Journal of the European Communities 2001:L194:26-34.

5 Lee S, Ling PM, Glantz SA. The vector of the tobacco epidemic: tobacco industry practices in low and middle-income countries. Cancer Causes Control 2012;23(suppl 1):117-29.

6 Joossens L, Gilmore AB. The transnational tobacco companies' strategy to promote Codentify, their inadequate tracking and tracing standard. Tob Control 2013: published online 27 Apr.

7 Lee YO, Glantz SA. Menthol: putting the pieces together. Tob Control 2011;20(suppl 2):ii1-7.
8 Ferris Wayne G, Connolly GN. Application, function, and effects of menthol in cigarettes: a survey of tobacco industry documents. Nicotine Tob Res 2004;6(suppl 1):S43-e54. Davis SP, McClave-Regan AK, Rock VJ, Kruger J, Garrett BE. Perceptions of menthol cigarette use among US adults and adult smokers: findings from the 2009 HealthStyles survey. Nicotine Tob Res 2010;12(suppl 2):S125-35.

10 Wright O. EU's "shame" as it caves in to lobbying by tobacco giants over the sale and advertising of cigarettes. Independent 2013. www.independent.co.uk/news/world/europe/ eus-shame-as-it-caves-in-to-lobbying-by-tobacco-giants-over-the-sale-and-advertisingof-cigarettes-8866335.html.

11 McKee M. E-cigarettes and the marketing push that surprised everyone. BMJ 2013;347:55780.

Cite this as: BMJ 2013;347:f6196

(c) BMJ Publishing Group Ltd 2013 